УДК $351 / 346.548$

DOI https://doi.org/10.32851/tnv-pub.2021.3.2

\title{
ДЕРЖАВНЕ РЕГУЛЮВАННЯ ВІДНОСИН ДРОПШИПІНГУ В УКРАЇНІ
}

\author{
Бронат Ю.В. - асистент кафедри публічного управління та права \\ Херсонського державного аграрно-економічного університету \\ ORCID: 0000-0001-9224-2450
}

У статті досліджено проиес зростання обсягу продажів товарів із застосуванням засобів електронної комериії. Наведено декілька підходів до визначення нового для української правової системи економічного явища - дропшипінгу. Сформовано власне визначення економічної моделі діяльності посередників у галузі реалізації торгівлі та послуг.

Виокремлено суттєві економічні переваги застосування дропшипінгу, серед яких: відсутність необхідності вкладання великого статутного капіталу, відсутність ризику втрати капіталу й оборотних засобів, проста форма легалізаиії діяльності, відсутність необхідності нести витрати на обслуговування складських приміщень та адміністрування почтових відправлень. Визначені основні види правочинів, щсо укладаються між учасниками, котрі вступають у відносини дропшипінгу. Окреслено основні характеристики застосування агентських угод при здійсненні реалізації товарів $і$ послуг кінцевим споживачам.

Проаналізовано основні проблемні питання державного регулювання відповідальності посередників за прострочення доставки товару, поставки виробником/постачальником товару неналежної якості та не повідомлення покупия про реальний правовий статус такого посередника.

Зроблено висновок, щуо очікується подальше розповсюдження застосування моделі дропшипінгу в Україні серед малого підприємництва з метою реалізації товару та послуг виробника/постачальника через посередників. Збільшення кількості правочинів за участі дропшиперів має величезний вплив на розвиток електронної комериії.

У статті доведено необхідність подальшого дослідження правового регулювання діяльності дропшиперів, щуо потребує законодавчого закріплення поняття дропшипінгу, визначення кола учасників, котрі беруть участь у такій моделі реалізачї товару, а також уточнення чинних положень законодавства про захист прав споживачів.

Ключові слова: державне регулювання, дропшипінг, електронна торгівля, відповідальність суб' єктів господарювання.

\section{Bronat Y.V. State regulation of dropshipping relations in Ukraine}

The article studies the process of volume growth in the sales of goods using e-commerce tools. Several approaches are given to the definition of a new economic phenomenon for the Ukrainian legal system - dropshipping. The definition of the economic model of intermediaries'activity in the sale of trade and services has been formed.

Significant economic advantages of using dropshipping are highlighted, including: no need to invest large nominal capital, no risk of loss of capital and working capital, a simple form of legalization of activities, no need to bear the cost of maintaining warehouses and administering items. The main types of transactions concluded between participants entering into dropshipping relations have been determined. The main characteristics of agency agreements application in the implementation of the sale of goods and services to end consumers are indicated.

The main problematic issues of state regulation of the liability of intermediaries for delayed delivery of goods, delivery by the manufacturer / supplier of goods of inadequate quality and failure to notify the buyer about the real legal status of such an intermediary are analyzed.

As a result of the study it was concluded that the further spread of dropshipping model use in Ukraine among small businesses is expected in order to sell goods and services of the manufacturer / supplier through intermediaries. The increase in the number of deals involving dropshippers will certainly have a huge impact on the development of e-commerce.

The article proves the need for further research into the legal regulation of the activities of dropshippers, which requires legislative consolidation of dropshipping concept, determination of the circle of participants in such a model of product sales, as well as clarification of the actual provisions of consumer protection legislation.

Key words: government regulation, dropshipping, onlibe trading, responsibility of business entities. 
Постановка проблеми. Торговельно-економічні відносини в Україні щороку займають дедалі більшу частку ВВП країни. Розвиток інформаційних технологій, застосування нових методів продажів, розширення кількості агентів і комерційних посередників і дедалі більше використання мережі Інтернет і соціальних мереж для реалізації товарів і послуг призводить до появи нових форм взаємодій суб'єктів господарювання. Так, останніми роками підприємці сектору торгівлі товарами широкого вжитку дедалі частіше застосовують у своїй діяльності альтернативну, на противагу традиційним (прямим продажам), форму просування товарів, таку як дропшипінг. Інститут дропшипінгу є доволі новим для українського ринку збуту, окрім того, чинним законодавством не визначено ані поняття дропшипінгу, ані сутності таких відносин між суб'єктами господарювання та кінцевими споживачами, що зумовлює актуальність нашого дослідження.

Аналіз останніх досліджень і публікацій. Питанням провадження інструменту продажів через посередників, дропшипінгу, визначенням його особливостей, виявленням економічних переваг і маркетингових стратегій займалися такі вчені й економісти-практики, як М.Л. Калужський, В. Федоричак, В.М. Ходиревська, І.В. Припадчева, Є.М. Заїкін, Г.А. Яшева, Т.П. Прокшіна, О.В. Онищенко та ін., однак у контексті державного регулювання зазначених відносин дропшипінгу дослідження відсутні, що свідчить про необхідність і доцільність проведення детального вивчення цього явища.

Формування цілей статті. Мета дослідження полягає у вивченні нового типу суспільно-економічних відносин дропшипінгу та державної політики щодо регулювання таких відносин на підставі світового і вітчизняного досвіду.

Виклад основного матеріалу. Кінцевий споживач в Україні ще до початку запровадження карантинних заходів пов'язаних із пандемією Covid-19, дедалі частіше здійснював купівлі товарів і послуг через мережу Інтернет із застосуванням електронних засобів оплати. Так, у 2016 р. було придбано на 73\% більше товарів, ніж у 2015 р. - на суму 8,5 млрд грн. Кількість замовлень за рік зросла на $61 \%$ [1].

Така тенденція зросту показників залишилася і з упровадженням карантинних заходів задля запобігання поширенню короновірусної хвороби Covid-19, що лише сприяло збільшенню кількості онлайн-продажів порівняно з офлайн (фактичними) магазинами.

За оцінками групи компаній EVO (Prom.ua, Bigl.ua, Crafta.ua, Kabanchik. ua, Goodini.ua), загальна сума фізичних товарів і послуг, які придбали українці в Інтернеті у 2020 р., сягнула 107 млрд грн. Це на 41\% більше, ніж 2019 р. Зросла і кількість онлайн-оплати - щонайменше на 50\% [2].

За таких умов є характерним збільшення кількості суб' єктів господарювання, які реалізують товар через організацію бізнес-процесів за моделлю «дропшипінг», оскільки це мінімізує маркетингові й операційні затрати виробника/продавця на реалізацію продукції кінцевому споживачу.

Так, дедалі більше розповсюджується новий вид відносин між бізнесом, відомий як «дропшипінг», однак якщо для української правової системи такий вид діяльності є новим, то для країн загального права дропшипінг вже понад 15 років є одним із поширених способів реалізації товарів і послуг.

Наприклад, на ринку США активно діють понад 1000 дропшипперів із обсягом продажів 475 млн дол., що становить близько $2 \%$ від загального обсягу оптової торгівлі [3, с. 250]. 
Дропшиппінг (drop shipping із англ. - пряма поставка) - це вид підприємництва, за якого посередником (дропшипером) продається товар фірми-виробника. Такий вид діяльності зустрічається найчастіше в Інтернеті [4].

Тобто товар закуповується клієнтом у посередника під замовлення (на сайті, у соціальних мережах чи будь-яких інших засобах Інтернет-торгівлі). Посередник (дропшипер) передає дані про таке замовлення й відомості про покупця виробнику/продавцю, й останній здійснює продаж товару від свого імені через засоби поштового зв'язку та/або кур'єрську службу.

Саме відправлення товару покупцеві безпосередньо від постачальника, а не від дропшипера становить головну особливість дропшипінгу. У цьому він схожий на транзитну торгівлю, але без переходу права власності на товар до дропшипера [5].

Оскільки товар не переходить у власність посередника, то у схемі дропшипінгу між виробником і посередником (дропшипером) договір купівлі-продажу не укладають. Право власності на товар переходить одразу від постачальника/виробника до покупця.

Водночас у клієнта/покупця при оформленні замовлення у посередника не виникає жодних правовідносин із постачальником, про існування якого він може бути не обізнаний.

Варто враховувати, що дропшипер виконує лише обмежене угодою з виробником/продавцем товару або послуги коло обов'язків, виступаючи третьою стороною - посередником у відносинах між виробником/продавцем і клієнтом (кінцевим споживачем). Такий правовий статус посередника або агента суттєво впливає на зміст цих обов'язків і характер персональної відповідальності дропшипера.

Дропшипінгом називають модель бізнесу, яка передбачає, що суб'єкт діяльності - посередник купує товар у виробника тоді, коли отримає замовлення на нього, за умов його попередньої оплати з боку покупця або він передає замовлення оптовику, а потім сам його відправляє, нараховуючи комісійну винагороду. Фактично це договір прямого постачання, що передбачає отримання доходу від реалізації, не будучи виробником цього конкретного продукту і навіть не маючи такої продукції у наявності. У моделі дропшипінгу за доставку відповідає сам виробник. Таким чином, дропшипінг звільняє підприємця від необхідності вирішення низки питань, таких як облік і зберігання товару, логістика тощо, дозволяючи зосередитися на маркетингу, рекламі та розширювати обсяг продажів [6].

Отже, дропшипінг - інструмент, механізм, засіб продажу/реалізації попередньо обраного покупцем конкретного товару чи послуги, за якого покупець (кінцевий споживач) здійснює замовлення у посередника (дропшипера), котрий діє від власного імені, реалізуючи товар та/або послугу виборника/продавця на підставі агентського договору, договору комерційного посередництва чи договору комісії, покупець (кінцевий споживач) може не бути обізнаним про правовий статус посередника (дропшипера).

Економічний ефект посередника (дропшипера) формується за рахунок різниці між оптовою та роздрібною ціною, за якою він продає товар клієнтові. Ключовою відмінністю цього виду діяльності $є$ те, що придбаний товар покупцеві відправляють безпосередньо зі складу виробника.

Середньостатистична частка трансакційних витрат дропшиипперів, зумовлена відмовою від дорогих функцій (складування, вантажно-розвантажувальних робіт і т. д.), становила близько 6,4\% від загального обсягу продажів проти $21,0 \%$ у повнофункціональних оптових торговців [3, с. 250]. 
Суттєвими економічними перевагами моделі організацій бізнесу дропшиперами є:

1. Відсутність необхідності вкладання статутного капіталу великого розміру для здійснення операційних витрат.

2. Відсутність ризику втрати капіталу й оборотних засобів, оскільки дропшипер зазвичай працює за процент від продажів або лише за попередньою оплатою товару чи послуги, тож понести ризик втрати грошових коштів через недобросовісного покупця неможливо.

3. Оранізаційно проста форма легалізації діяльності через реєстрацію фізичної особи-підприємця, без необхідності створення юридичної особи приватного права. Порівняно нескладне адміністрування податкових зобов'язань і низькі ставки єдиного податку.

4. Відсутність необхідності нести витрати на обслуговування складських приміщень, оскільки відправлення товару здійснюється зі складу виробника/продавця самостійно, напряму кінцевому споживачу.

5. Відсутність необхідності адміністрування поштових відправлень адресних замовлень товарів.

Найбільш розповсюдженими видами правочинів, що укладаються між між дропшиперами та виробниками/продавцями, є комісійна торгівля, або торгівля за агентським договором, однак слід враховувати, що організація дропшипінгу за агентським договором може мати два варіанти оформлення відносин:

- агентський договір із покупцем (на закупівлю);

- агентський договір із виробником/постачальником (на реалізацію).

Агентські відносини надають повноваження агенту на вчинення відповідних дій на підставу договору, але зазвичай у схемі дропшипінгу письмових договорів не укладають, а оформлюють так звані договори приєднання в електронній формі, коли друга сторона висловлює згоду з офертою, розміщеною на сайті [7, с. 665].

Торгова інфраструктура дропшипінгу значно відрізняється від інфраструктури у традиційній торгівлі. Дропшипінг більше нагадує ярмаркову торгівлю $з$ великим числом роздрібних продавців і покупців. «Розміри замовлених через Інтернет партій товарів набагато менші, але їх число - набагато більше...», - відзначають Т. Кент і О. Омар [8].

Однак за великої економічної вигоди від здійснення діяльності посередника внаслідок зменшення операційних витрат, витрат на зберігання та транспортування товару та іншого слід розібратися у правовій природі відповідальності дропшипера перед покупцем (кінцевим споживачем), наприклад за несвоєчасної поставки товару постачальником або поставки товару неналежної якості.

Окрім того, у моделі бізнесу «дропшипінг» існують також й інші слабкі сторони, а саме повернення товару, який із тих чи інших причин не підійшов клієнту.

Відповідно ст. 4 Закону України «Про захист прав споживачів» споживачі під час укладення, зміни, виконання та припинення договорів щодо отримання (придбання, замовлення тощо) продукції, а також при використанні продукції, яка реалізується на території України, для задоволення своїх особистих потреб мають право на захист своїх прав державою; належну якість продукції й обслуговування; безпеку продукції; необхідну, доступну, достовірну та своєчасну інформацію державною мовою про продукцію, іiі кількість, якість, асортимент, іiї виробника (виконавця, продавця) за Законом України «Про забезпечення функціонування української мови як державної»; відшкодування майнової та моральної шкоди, завданої внаслідок недоліків продукції (дефекту у продукції), відповідно до закону [9]. 
Згідно з положеннями ст. 6 Закону України «Про захист прав споживачів» продавець (виробник, виконавець) зобов'язаний передати споживачеві продукцію належної якості, а також надати інформацію про цю продукцію [9].

Тож при використанні форми реалізації товарів через дропшиперів (посередників) споживач має право не тільки отримати всю належну інформацію про продукцію, але й бути обізнаним про правовий статус такого дропшипера 3 метою ідентифікувати реального виробника/постачальника товару у разі потреби захисту прав своїх прав відповідно до закону, однак, виходячи з відсутності у чинному законодавстві навіть визначення дропшипера, можна сказати, що на практиці під час реалізації товару такі посередники не повідомляють покупців про свій правовий статус, у тому числі про обсяг персональної відповідальності та коло питань у межах відповідальності саме виробника/постачальника.

Така ситуація призводить до того, що покупець під час купівлі товару може бути введений в оману щодо правового характеру правочину, який укладається між ним та іншою стороною, котру покупець і вважає виробником.

Оскільки відносини дропшипінгу розповсюджуються переважно на онлайн-торгівлю, слід звернутися до Закону України «Про електронну комерцію», відповідно до ст. 17 якого сторони електронних правочинів відповідають за невиконання своїх зобов'язань у порядку, визначеному законом або договором. Постачальник послуг проміжного характеру в інформаційній сфері несе відповідальність за невиконання своїх зобов'язань у порядку, визначеному законом або відповідним договором про надання таких послуг. Постачальник послуг проміжного характеру несе відповідальність за забезпечення технічного захисту інформації та здійснення контролю за ним у порядку, визначеному законодавством або відповідним договором про надання таких послуг. Постачальник послуг проміжного характеру несе відповідальність за зміст переданої й отриманої інформації та за шкоду, завдану внаслідок використання результатів таких послуг, за умови відсутності у його діях будь-якої з обставин, що звільняють його від відповідальності, встановлених ст. 9 цього Закону [10].

Однак не варто плутати дропшипера 3 постачальником послуг проміжного характеру, оскільки останній відповідно до ч. 4 ст. 9 Закону України «Про електронну комерцію» не $\epsilon$ стороною електронного правочину, предметом якого виступають товари, роботи або послуги, інші, ніж послуги проміжного характеру в інформаційній сфері (реєстрація доменних імен або IP-адрес, присвоєння інших мережевих ідентифікаторів, фіксація часу відправлення/надходження електронного повідомлення, надання доступу до мережі Інтернет та інших інформаційно-телекомунікаційних систем тощо), і не несе відповідальності за зміст переданої чи отриманої інформації та за шкоду, завдану внаслідок використання результатів таких послуг, за умови, що він не $\epsilon$ ініціатором передачі такої інформації, не обирає iї одержувача та не може змінити ії зміст [10].

Оскільки дія зазначеного закону розповсюджується на порядок вчинення електронних правочинів із застосуванням інформаційно-телекомунікаційних систем і визначає права й обов'язки учасників відносин у сфері електронної комерції, то з аналізу норм закону можна дійти висновку, що і дропшипери під час здійснення господарської діяльності несуть відповідальність, визначену законом (у тому числі Законом України «Про захист прав споживачів») і договором, укладеним між ним і покупцем, зазвичай у формі приєднання до публічного договору (оферти), однак характертакоївідповідальності,іїмежі,розмежуваннязвідповідальністювиробника/ постачальника залишаються невизначеними у чинних нормативно-правових актах. 
Висновки. Дропшипінг в Україні - це розповсюджена серед малого підприємництва модель реалізації товару та послуг виробника/постачальника через посередників, які називаються дропшиперами та діють від власного імені, реалізуючи товар та/або послугу виборника/продавця на підставі агентського договору, договору комерційного посередництва чи договору комісії. Покупець (кінцевий споживач) може не бути обізнаним про правовий статус такого посередника (дропшипера).

Збільшення кількості правочинів за участі дропшиперів має величезний вплив на розвиток електронної комерції, однак, як і будь-яке нове для економіки явище, правове регулювання такої діяльності потребує законодавчого закріплення поняття дропшипінгу, визначення кола учасників, що беруть участь у такій моделі реалізації товару, а також уточнення дійсних положень законодавства про захист прав споживачів із метою забезпечення захисту прав покупців і розмежування відповідальності дропшиперів і виробників/постачальників за надання належної інформації про правову природу правочину, свій правовий статус та особу реального постачальника, а також несвоєчасну поставку товару або поставку товару неналежної якості. Ці питання визначають напрями подальших досліджень державного регулювання відносин дропшипінгу.

\section{СПИСОК ВИКОРИСТАНОЇ ЛІТЕРАТУРИ:}

1. E-commerce в Україні: підсумки 2016. Топові тренди 2017. Logist.Fm : веб-сайт. URL: http://logist.fm/publications/e-commerce-v-ukrayini-pidsumki-2016topovi-trendi-2017 (дата звернення: 06.12.2021).

2. 107 млрд гривень витратили українці на покупки в інтернеті у 2020 році група компаній EVO. Портал електронних послуг Дія.Бізнес : веб-сайт. URL: https://business.diia.gov.ua/en/cases/prodazi/107-mlrd-griven-vitratili-ukrainci-napokupki-v-interneti-u-2020-roci-grupa-kompanij-evo (дата звернення: 06.12.2021).

3. Прокшіна Т.П. Маркетинг : підручник. Ростов-на-Дону : Фенікс, 2010. 314 с.

4. Дропшиппинг. Преимущества и недостатки такого вида деятельности. Geniusmarketing : веб-сайт. URL: https://geniusmarketing.me/lab/dropshippingpreimushhestva-i-nedostatki-takogo-vidadeyatelnosti/ (дата звернення: 05.12.2021).

5. Алиев Т. Дропшиппинг: выгодное виртуальное посредничество? Buhgalteria caŭm бухгалтеров : веб-сайт. URL: http://www.buhgalteria.com.ua/Hit. html?id=4891 (дата звернення: 05.12.2021).

6. Федоричак В.М. Дропшипінг як схема роботи інтернет-магазину: плюси і мінуси. Lemarbet : веб-сайт. URL: https://lemarbet.com/razvitie-internet-magazina/ dropshipping-kak-shema-raboty-internet-magazina-plyusy-i-minusy/ (дата звернення: 06.12.2021).

7. Онищенко О.В. Дропшипінг як ефективна система ведення електронної торгівлі. Формування ефективної моделі розвитку підприємства в умовах ринкової економіки : матеріали наук.-практ. конф., 10 листопада 2017 р. Житомир, 2017. С. $665-667$.

8. Кент Т., Омар О. Роздрібна торгівля. Москва : Юніті-Дана, 2007. 697 с.

9. Прозахист прав споживачів : Закон України від 12 травня 1991 р. № 1023-XII/ Верховна Рада України. URL: https://zakon.rada.gov.ua/laws/show/1023-12\#Text (дата звернення: 06.12.2021).

10. Про електронну комерцію : Закон України від 03 вересня 2015 р. № 675VIII / Верховна Рада України. URL: https://zakon.rada.gov.ua/laws/show/675-19\#n198 (дата звернення: 06.12.2021). 


\section{REFERENCES:}

1. Sait Logist.Fm [Site of Logist.Fm]. logist.fm Retrieved from http://logist.fm/ publications/e-commerce-v-ukrayini-pidsumki-2016-topovi-trendi-2017 [in Ukrainian].

2. Sait Portal elektronnykh posluh Diia.Biznes [Site of Portal of electronic services Action.Business]. business.diia.gov.ua. Retrieved from https://business.diia.gov.ua/en/ cases/prodazi/107-mlrd-griven-vitratili-ukrainci-na-pokupki-v-interneti-u-2020-rocigrupa-kompanij-evo [in Ukrainian].

3. Prokshina, T.P. (2010). Marketynh [Marketing]. Rostov-na-Donu: Feniks [in Ukrainian].

4. Sait Geniusmarketing [Site of Geniusmarketing]. geniusmarketing.me Retrieved from https:/geniusmarketing.me/lab/dropshipping-preimushhestva-i-nedostatki-takogo-vidadeyatelnosti [in Ukrainian].

5. Alyev, T., Dropshypynh: vuhodnoe vyrtualnoe posrednychestvo? [Dropshipping: profitable virtual intermediation?]. Retrieved from http://www.buhgalteria.com.ua/ Hit.html?id=4891 [in Russian].

6. Fedorychak, V.M., Dropshyppinh yak skhema roboty internet-mahazynu: pliusy $i$ minusy. [Dropshipping as a scheme of online shopping: pros and cons]. Retrieved from https://lemarbet.com/razvitie-internet-magazina/dropshipping-kak-shema-raboty-internet-magazina-plyusy-i-minusy/ [in Ukrainian].

7. Onyshchenko, O.V. (2017). Dropshypinh yak efektyvna systema vedennia elektronnoi torhivli. [Dropshipping as an effective system of e-commerce]. Naukovo-praktychna konferentsiia "Formuvannia efektyvnoi modeli rozvytku pidpryiemstva v umovakh rynkovoi ekonomiky" - Proceedings of the Scientific and Practical Conference "Formation of an effective model of enterprise development in a market economy". (pp. 665-667). Zhytomyr. [in Ukrainian].

8. Kent, T., \& Omar, O. (2007). Rozdribna torhivlia [Retail]. Moskva: Yuniti-Dana [in Ukrainian].

9. Zakon Ukrainy "Pro zakhyst prav spozhyvachiv" [The Law of Ukraine "On consumer protection"]. (n.d.). zakon.rada.gov.ua. Retrieved from: https://zakon.rada.gov.ua/ laws/show/1023-12\#Text [in Ukrainian].

10. Zakon Ukrainy "Pro elektronnu komerciu" [The Law of Ukraine "About e-commerce"]. (n.d.). zakon.rada.gov.ua. Retrieved from https://zakon.rada.gov.ua/laws/show/ 675-19\#n198 [in Ukrainian]. 